\title{
MHC class II exacerbates demyelination in vivo independently of T cells
}

\author{
Meenaxi M. Hiremath ${ }^{1,2}$, Vivian S. Chen ${ }^{1,2}$, Kinuko Suzuki ${ }^{2,3,4}$, Jenny P. -Y. Ting ${ }^{1,4,5}$, and \\ Glenn K. Matsushima ${ }^{1,2,4,6,{ }^{*}}$ \\ ${ }^{1}$ Department of Microbiology and Immunology, University of North Carolina Chapel Hill, NC \\ 27599 \\ ${ }^{2}$ UNC Neuroscience Center, University of North Carolina Chapel Hill, NC 27599 \\ ${ }^{3}$ Department of Pathology and Laboratory Medicine, University of North Carolina Chapel Hill, NC \\ 27599 \\ ${ }^{4}$ Curriculum in Neurobiology, University of North Carolina Chapel Hill, NC 27599 \\ ${ }^{5}$ Lineberger Comprehensive Cancer Center, University of North Carolina Chapel Hill, NC 27599 \\ ${ }^{6}$ Program for Molecular Biology and Biotechnology University of North Carolina Chapel Hill, NC \\ 27599
}

\begin{abstract}
We have shown previously the importance of MHC class II for central nervous system remyelination; however, the function of MHC class II during cuprizone-induced demyelination has not been examined. Here, we show that $I-A_{\beta}{ }^{-1-}$ mice exhibit significantly reduced inflammation and demyelination. $R A G-1^{-l-}$ mice are indistinguishable from controls, indicating $\mathrm{T}$ cells may not play a role. The role of MHC class II depends on an intact cytoplasmic tail that leads to the production of IL- $1 \beta$, TNF- $\alpha$, and nitric oxide, and oligodendrocyte apoptosis. Thus, the function of MHC class II cytoplasmic tail appears to increase microglial proliferation and activation that exacerbates demyelination.
\end{abstract}

\section{Introduction}

The Major Histocompatibility Complex class II (MHC II) molecules present antigenic peptides to $\mathrm{CD}^{+} \mathrm{T}$ cells through interactions with both the $\mathrm{T}$ cell receptor (TCR) and the CD4 molecule (Doyle and Strominger, 1987; Germain, 1994; Jones et al., 2006; Konig et al., 1992; Konig et al., 1995). Enhancement of MHC class II has been found to be important for the education of $\mathrm{CD}^{+} \mathrm{T}$ cells and $\mathrm{T}$ cell-mediated immune responses, while the elimination of MHC II is frequently associated with the ablation of such responses (Grusby and Glimcher, 1995). Previous in vivo studies have primarily focused on the effects of MHC II antigens as ligands for the TCR and not as a receptor for signaling cell activation (Thomson, 1995; Zamvil et al., 1985).

\footnotetext{
(C) 2008 Elsevier B.V. All rights reserved.

*To whom correspondence should be addressed (gkmats@med.unc.edu). .
}

Publisher's Disclaimer: This is a PDF file of an unedited manuscript that has been accepted for publication. As a service to our customers we are providing this early version of the manuscript. The manuscript will undergo copyediting, typesetting, and review of the resulting proof before it is published in its final citable form. Please note that during the production process errors may be discovered which could affect the content, and all legal disclaimers that apply to the journal pertain. 
MHC II molecules have been observed in mouse brains (Hauser et al., 1983; Hickey and Kimura, 1988; Ting et al., 1981; Wong et al., 1984) and in a number of neurological disorders (Hickey, 1991; Mattiace et al., 1990; McGeer et al., 1988a; McGeer et al., 1988b). In diseases involving viral infections or experimental autoimmune encephalitis (EAE), where T cell involvement is prominent, the function of MHC II is primarily that of antigen presentation by microglia/macrophages (Fritz and McFarlin, 1989; Zamvil and Steinman, 1990). Unlike normal mouse brain, there is little to no expression of MHC II in healthy human brain (Kreutzberg, 1996); yet in neurological disorders, such as Alzheimer's disease, Huntington's disease, and Parkinson's disease, $\mathrm{MHC} \mathrm{II}^{+}$microglial/macrophage cells are present. Interestingly, T cells do no appear to be involved in these CNS disorders (Hickey et al., 1991; Mattiace et al., 1990; McGeer et al., 1988a; McGeer et al., 1988b; Zamvil et al., 1985). In addition, even in MS lesions, microglia/macrophages have been found in the absence of significant T cell infiltration (Barnett et al., 2006; Li et al., 1993; Prineas, 2002; Raine, 1994). Thus, the function of MHC II and the significance of T cells in these diseases are important issues that need to be clarified.

We previously used $I-A_{\beta}{ }^{-1-}$ twitcher mice, a murine model for human globoid cell leukodystrophy or Krabbe's disease, to show that the absence of MHC II on microglia/ macrophages reduces CNS demyelination. In the wild type $\left(I-A_{\beta}{ }^{+/+}\right)$twitcher mice, demyelination is accompanied by increases in microglia/macrophages with few detectable $\mathrm{T}$ cell infiltrates (Matsushima et al., 1994). Due to the near absence of T cells in the demyelinating brain of these mice, it is plausible that MHC II may not be functioning in antigen presentation. An alternative role for MHC II is in signal transduction. There are ample reports that show the triggering of MHC II on T cells, B cells, and monocytes leads to results in intracellular signaling, activation, differentiation, and/or the production of proinflammatory cytokines (Andre et al., 1994; Bishop and Haughton, 1986; Cambier et al., 1987; Espel et al., 1996; Fast et al., 1989; Harton and Bishop, 1993; Mehindate et al., 1996; Nabavi et al., 1992; Nabavi et al., 1989; Odum et al., 1991; Trede et al., 1991; Wade et al., 1989). However, all of these studies were performed in vitro with cultured cells, and the in vivo physiological significance is less clear.

To further investigate the role of MHC II on microglia/macrophages during CNS disease, we used cuprizone intoxication, a copper-chelating neurotoxin, to induce demyelination (Blakemore, 1972; Blakemore, 1973; Ludwin, 1978; Suzuki and Kikkawa, 1969). We have previously shown that C57BL/6 mice that were exposed to a cuprizone-supplemented diet resulted in a predictable course of demyelination and pathology (Hiremath et al., 1998; Morell et al., 1998). During cuprizone intoxication, the perturbation of oligodendrocytes is evident by the dramatic inhibition of transcripts for myelin-basic protein (MBP), myelinassociated glycoproteins (MAG), and ceramide galactosyl transferase (Morell et al., 1998). Subsequently, the GST-pi mature oligodendrocytes are depleted from the demyelinating lesion by apoptosis (Mason et al., 2000). Cuprizone-induced demyelination is similar to the twitcher model in that microglia/macrophage accumulate at the site of demyelination (Hiremath et al., 1998; Morell et al., 1998). However, in contrast to the twitcher mouse model, cuprizone-induced demyelination is characterized by the accumulation of resident microglia with very few (<4\%) peripheral macrophages (McMahon et al., 2002; Yagi et al., 2004). Moreover, this is without obvious $T$ cell accumulation presumably due to the intactness of the blood-brain-barrier (Bakker and Ludwin, 1987; Kondo et al., 1987). The cuprizone intoxication model can be conveniently studied for mutant mice on the C57BL/6 background (Hiremath et al., 1998).

The current report shows cuprizone-induced demyelination and pathology in $I-A_{\beta}{ }^{-I-}$ mice (Grusby et al., 1991) demonstrated a significant decrease in acute demyelination and pathology compared to wild type mice. Interestingly, mice with a truncated $I-A_{\beta}\left(I-A_{\beta}{ }^{t r}\right)$ 
which have intact extracellular and transmembrane sequences but lacks the cytoplasmic domain (Smiley et al., 1995; Smiley et al., 1996) exhibited similar responses as $I-A_{\beta}{ }^{-I-}$ mice. Furthermore, $I-A_{\beta}{ }^{-1-}$ and $I-A_{\beta}{ }^{t r}$ mice had fewer proliferating microglia/macrophages and reduced amounts of TNF- $\alpha$, IL-1 $\beta$, and nitric oxide in the brain compared to wild type mice, suggesting a role for MHC II in the activation of microglia/macrophages. Additionally, demyelination and pathology studies from cuprizone-treated recombinase activating gene-1 knockout $\left(R A G-1^{-I^{-}}\right)$mice show that the role of MHC II is likely independent of $\mathrm{T}$ cells. The data provide in vivo evidence for a role for MHC II molecules other than antigen presentation to $\mathrm{T}$ cells.

\section{Materials and Methods}

\section{Mice and tissue preparation}

C57BL/6J, I- $A_{\beta}{ }^{-1-}, I-A_{\beta}{ }^{t r}$, and $R A G-I^{-1-}$ male mice at five to six weeks old were either purchased from the Jackson Laboratory (Bar Harbor, Maine, USA) or bred and maintained in our pathogen-free animal facility at UNC. Only eight to ten weeks old age-matched animals were used in an experiment. Cuprizone was mechanically mixed into ground Breeder chow 2000 (Purina, Richmond, IN) to make a $0.2 \%$ mixture by a weight-to-weight ratio and mice were treated as previously described (Hiremath et al., 1998). Mouse brains were harvested at appropriate time points and processed for paraffin sections as previously described (Hiremath et al., 1998). Briefly, paraffin-embedded tissues were sectioned at $5 \mu \mathrm{m}$ in thickness at the level of section 251 according to Sidman's mouse atlas (Sidman et al., 1971). For frozen sectioning, brains were harvested and frozen in an isopentane freezing bath. They were then sectioned by a cryostat at $5 \mu \mathrm{m}$ in thickness at the level of section 241-251 according to Sidman's mouse atlas (Sidman et al., 1971).

\section{Evaluation of demyelination}

For routine histology, the sections were stained with Luxol fast blue-periodic acid Schiff (LFB-PAS) stain and demyelination was evaluated as previously described (Hiremath et al., 1998). Briefly, three independent readers in a double-blind fashion scored LFB-PAS-stained sections from zero to three. Zero was equivalent to the myelin status of a mouse not treated with cuprizone, whereas a score of three was total demyelination usually observed at six weeks of treatment with cuprizone. In addition, cellularity was scored on a scale of zero to three in these samples as an estimate of the number of nuclei-containing cells infiltrating demyelinating regions. Zero represented few nuclei as in the untreated animal and three represented the heavy accumulation of nuclei in the myelin tract following complete demyelination.

\section{Immunohistochemical staining}

MHC II staining was performed according to manufacturer's protocol (Serotec, Raleigh, $\mathrm{NC}$ ). Briefly, $5 \mu \mathrm{m}$ thick fresh frozen sections from brains of mice exposed to cuprizone for 3 weeks were post-fixed with acetone. Sections were treated with $0.3 \%$ peroxide for $5 \mathrm{~min}$ at $4^{\circ} \mathrm{C}$ to eliminate endogenous peroxidase activity. Sections were then treated with primary or isotype control antibody overnight at $4{ }^{\circ} \mathrm{C}$, followed by FITC-conjugated secondary antibody for $2 \mathrm{hrs}$ at room temperature. To verify the degree of microglial/macrophage response, paraffin sections of the cerebrum were processed for immunocytochemical detection of microglia/macrophages with a lectin RCA-1 (Sigma, St. Louis, MO), using the Autoprobe III kit with streptavidin-conjugated peroxidase base (Biomed Co., Foster City, CA) as previously described (Hiremath et al., 1998). All scores and quantitation of cells in each coronal section of the corpus callosum were typically conducted at two sites, immediately lateral of midline (see labeled box in Figure 1). 
GST-pi staining for mature oligodendrocytes was performed on paraffin sections. Sections were deparaffinized, permeabilized with $0.1 \%$ Triton-X-100, and unmasked with $1 \mathrm{mg} / \mathrm{ml}$ trypsin in $0.05 \mathrm{M} \mathrm{HCl}$ solution at $37^{\circ}$ for 15 minutes. Sections were then blocked and treated with a 1:1000 dilution of rabbit anti-pi GST (Biotrin International Inc., Newton, MA) overnight at $4^{\circ} \mathrm{C}$. Sections were then washed with PBS and treated with FITC conjugated anti-rabbit antibody (Vector Laboratories) for 30 minutes at room temperature. Sections were washed with PBS and mounted with Vectashield (Vector Laboratories) prior to analysis.

To determine the number of proliferating microglia/macrophages, bromodeoxyuridine (BrdU) incorporation in microglia/macrophages was monitored by immunohistochemical colocalization. BrdU was injected intraperitoneally three times daily 2 days and 1 day prior to harvest, and once on the day of harvest as previously described (Taniike and Suzuki, 1995). Detection of BrdU was performed according to the manufacturer's instructions (Zymed, San Francisco, CA). Percentage indicated is the number of double-labeled BrdU and RCA- $1^{+}$cells was divided by the number of RCA- $1^{+}$microglia/macrophages.

Anti-nitrotyrosine staining was performed on paraffin sections. Sections were deparaffinized and treated with the sodium citrate unmasking solution from Vector Laboratories (Burlingame, CA). Sections were then blocked and incubated overnight at $4^{\circ} \mathrm{C}$ with 1:100 anti-nitrotyrosine antibody (Upstate Biotechnologies, Lake Placid, NY). Sections were then washed with PBS and treated with 1:100 anti-rabbit biotinylated antibody (Vector Laboratories) for 2 hours at room temperature. Sections were washed, treated with avidinFITC (Vector Laboratories) for $30 \mathrm{~min}$ at room temperature, and washed prior to analysis.

\section{Morphometric and immunohistochemical quantification of tissue}

The immunohistochemical-stained sections were used for the quantitative analysis of cells accumulating the corpus callosum during demyelination as previously described (Hiremath et al., 1998). Briefly, individual cells were counted based on nuclei in the corpus callosum using a morphometry system based on a Nikon FXA microscope (Garden City, NY) equipped with an Optronics TEC-470 CCD Video Camera System (Goleta, CA). Image processing, analyses, and measurements were carried out using the public domain NIH image program (http://rsb.info.nih.gov/nih-image/). The counted cells or stained tissue area for nitrotyrosine staining from $I-A_{\beta}{ }^{-I-}$ and $I-A_{\beta}{ }^{t r}$ cuprizone-treated animals were compared to wild type cuprizone-treated animals.

\section{Brain protein extracts and quantitation of cytokines}

Brains from cuprizone treated mice were harvested and sectioned to isolate the region containing the corpus callosum using a brain block. This brain section was frozen in liquid nitrogen and homogenized with a tissue homogenizer in a PBS/protease inhibitor cocktail. The homogenate was spun at maximum speed in a microfuge at $4^{\circ} \mathrm{C}$ and the supernatant was analyzed for presence of IL- $1 \beta$ and TNF- $\alpha$ by a standard sandwich EIA.

\section{Statistical Analyses}

All statistical analyses were conducted by one-way analysis of variance (ANOVA) test followed by the appropriate multiple comparisons test when appropriate.

\section{Results}

\section{MHC II expression increases with demyelination}

Brains from cuprizone-treated C57BL/6 mice were routinely analyzed for demyelination in the corpus callosum at levels 241-251 according to Sidman's atlas (Figure 1A) (Sidman et 
al., 1971). MHC II $^{+}$cells were detected early during cuprizone-induced demyelination and they remained significantly higher in numbers between weeks 3 and 6 (Figures 1B and 1C). An immunohistochemical colocalization analysis showed that MHC II is expressed exclusively by microglia/macrophages (data not shown).

\section{MHC II cytoplasmic tail exacerbates demyelination}

To determine if MHC II antigens exacerbates CNS histopathology, $I-A_{\beta}{ }^{-1-}$ C57BL/6 mice were exposed to the cuprizone diet, and the brains from these mice were analyzed for demyelination that is typically detectable by week 3. Luxol fast blue-periodic acid Schiffs (LFB-PAS) stains myelin blue, and counterstains the remaining tissue pink (Figure 2A). Cuprizone-fed $I-A_{\beta}{ }^{-I-}$ mice had significantly less demyelination at $3(\mathrm{p}<0.0003)$ and 3.5 $(\mathrm{p}<0.01)$ weeks than wild type mice (Figures $2 \mathrm{~A}$ and $2 \mathrm{~B})$. Concomitant with the reduced demyelination, there was also a significant reduction in cellularity at the 3 and 3.5 weeks time points (Figure 2B). Thus, the reduction in demyelination and cellularity in cuprizone intoxication corroborates our previous report that MHC II exacerbates demyelination in the twitcher mouse (Matsushima et al., 1994) and demonstrates a similar role for MHC II in two distinct models of demyelination.

Structure-function studies of $\mathrm{H}-2^{\mathrm{b}}$ MHC II have shown that the amino acids of the $\beta$-chain transmembrane and cytoplasmic domains are critical to signaling function of this molecule. To assess whether the cytoplasmic tail of MHC II is important in demyelinating disease, $I$ $A_{\beta}{ }^{\text {tr }}$ C57BL/6 mice that lack 13 amino acids of the carboxy-terminus of the $\beta$ chain were exposed to cuprizone (Smiley et al., 1995; Smiley et al., 1996). Although antigen presenting cells (APCs) from these mice show some alterations in in vitro antigen presentation, they do not exhibit any anomalous responses to in vivo antigenic challenges and express similar levels of MHC II antigen as wild type mice (Smiley et al., 1995; Smiley et al., 1996). Cuprizone-treated $I-A_{\beta}{ }^{t r}$ mice exhibited a dramatic reduction in demyelination at 3 $(\mathrm{p}<0.0003)$ and $3.5(\mathrm{p}<0.001)$ weeks compared to wild type mice (Figures $2 \mathrm{~A}$ and $2 \mathrm{~B})$. This reduction is similar to that observed with $I-A_{\beta}{ }^{-l-}$ mice. However, at week 4 , differences among the mice are not significant and by week $5, I-A_{\beta}{ }^{t r}$ or $I-A_{\beta}{ }^{-1-}$ mice were fully demyelinated similar to wild type mice (data not shown). In parallel with reduced demyelination, there was also a significant reduction in cellularity at the 3 and 3.5 weeks treatment time points (Figure $2 \mathrm{~B}$ ). Differences between the wild type mice and $I-A_{\beta}{ }^{\text {tr }}$ or $I$ $A_{\beta}{ }^{-1-}$ mice were greatest at 3.0 weeks, hence most of the subsequent studies were performed at this time point.

During cuprizone intoxication, mature oligodendrocytes undergo apoptosis and their depletion is believed to be the primary cause of demyelination (Mason et al., 2000). To determine whether the presence of MHC II on microglia/macrophages affects the myelinating cells, we quantified mature oligodendrocytes by immunohistochemistry using a GST-Pi stain (Cammer and Zhang, 1993; Mason et al., 2000). The number of GST-pi mature oligodendrocytes was significantly decreased in cuprizone-treated $I-A_{\beta}{ }^{+/+}$mice (approximately 530/mm ${ }^{2}$ ) at week 3 compared to untreated mice (approximately (1610/ $\mathrm{mm}^{2}$ ). In contrast, the number of mature oligodendrocytes in 3.0 week cuprizone-treated $I$ $A_{\beta}{ }^{-I-}$ and $I-A_{\beta}{ }^{t r}$ mice was approximately two-fold greater than wild type mice (approximately $1160 / \mathrm{mm}^{2}$ and $1366 / \mathrm{mm}^{2}$ vs. $530 / \mathrm{mm}^{2}$, respectively) at 3.0 weeks. The number of oligodendrocytes in the $\mathrm{I}-\mathrm{A}_{\beta}{ }^{-/-}$and $\mathrm{I}-\mathrm{A}_{\beta}{ }^{\text {tr }}$ mice was only slightly reduced when compared to untreated mice. These results implicate that the expression of MHC II molecules by microglia/macrophages may adversely affect the survival or maturation of mature oligodendrocytes. 


\section{MHC II cytoplasmic tail increases microglial proliferation, inflammatory cytokines, and oxygen radicals}

The pathology differences in the survival of mature oligodendrocyte in MHC II mutant mice were accompanied by differences in microglial proliferation, inflammatory cytokine synthesis, and the presence of oxygen radicals as shown below. Immunohistochemical staining for the RCA-1 lectin (Figure 3A), a marker for microglia/macrophages (Hiremath et al., 1998), revealed that wild type mice treated with cuprizone for 3 weeks had significantly increased numbers of microglia/macrophages compared to $I-A_{\beta}{ }^{-1-}$ and $I-A_{\beta}{ }^{t r}$ mice (Figure 3B). MHC II signaling has been shown to trigger proliferation of cells (Baluyut et al., 1993; Cambier and Lehmann, 1989; Lane et al., 1990; Mooney et al., 1990; Spertini et al., 1992).

We find the diminished numbers of microglia/macrophage in the $I-A_{\beta}{ }^{-l-}$ and $I-A_{\beta}{ }^{t r}$ mice can be partly explained by the reduced number of proliferating microglia/macrophages in these mice as measured by BrdU incorporation (Figure 4). The engagement of MHC II on monocytes is known to result in cytokine production, such as TNF- $\alpha$ and IL- $1 \beta$ (Scholl et al., 1992; Trede et al., 1991) which are likely detrimental to oligodendrocyte survival (Loughlin et al., 1994; Merrill, 1991; Selmaj and Raine, 1988). Significantly greater amounts of TNF- $\alpha$ and IL- $1 \beta$ were produced in the brains of cuprizone-treated wild type mice when compared to $I-A_{\beta}{ }^{-I-}$ or $I-A_{\beta}{ }^{\text {tr }}$ mice (Figure 5). Finally, activation through MHC II can result in increased nitric oxide synthesis in vitro (Hauschildt et al., 1993; Zembowicz and Vane, 1992). Nitrotyrosine reflects the presence of nitric oxide that reacts with free radicals to form peroxynitrites that bind proteins and convert tyrosine residues to nitrotyrosine (Beckman and Koppenol, 1996). An anti-nitrotyrosine staining (Figure 6) demonstrates increased nitric oxide activity in the cuprizone-treated wild type mice compared to cuprizone-treated $I-A_{\beta}{ }^{-1-}$ and $I-A_{\beta}{ }^{t r}$ mice. Thus, the cytoplasmic tail of MHC II expressed on microglia/macrophages appears to function in proliferation and in the production of noxious substances that correlates to mature oligodendrocyte depletion during demyelination.

\section{T cells are not required for activating MHC II}

$\mathrm{T}$ cells are rarely detected in the demyelinating lesions of cuprizone-treated mice, but they could engage MHC II molecules on microglia/macrophages via their T cell receptors. To definitively assess the role of lymphocytes, $R A G-1^{-/-}$mice that are deficient in $\mathrm{T}$ and $\mathrm{B}$ cells were exposed to cuprizone. The extent of demyelination and cellularity in $R A G-1^{-/-}$ mice was similar to wild type mice (Figure 7A). Furthermore, perivascular cuffing characteristic of lymphocyte infiltration was not observed in wild type mice or I-A mutant mice. $\mathrm{CD}^{+} \mathrm{T}$ cells were not detected in corpus callosum samples of 8 different wild type mice and only one $\mathrm{T}$ cell was detected in 2 of $7 \mathrm{I}-A \beta^{-1-}$ mice. These data would suggest that $\mathrm{T}$ cells do not play a significant role in cuprizone-induced demyelination. In addition, the number of microglia/macrophages was also similar (Figure 7B). These results suggest exclusion of lymphocytes in this disease model and suggest MHC II molecules on microglia/ macrophages do not function in antigen presentation.

\section{Discussion}

We have demonstrated that MHC II exacerbates cuprizone-induced demyelination. A likely role for MHC II molecules is to act as signaling receptors, presumably activating microglia/ macrophages during acute inflammation of the CNS. This is supported by the observation that the absence of the cytoplasmic tail of MHC II reduces histopathology similarly to mice devoid of MHC II molecules. However, this reduction is a delay in demyelination as I-A mutant mice are fully demyelinated by week 5 similar to wild type mice. In $I-A_{\beta}{ }^{t r}$ and $I$ $A \beta^{-/-}$mice undergoing demyelination, there are fewer proliferating $\mathrm{BrdU}^{+}$microglia and lower amounts of IL- $1 \beta$, TNF- $\alpha$ and nitric oxide, each of which may accelerate the depletion 
of mature oligodendrocytes. Lastly, the exacerbation of demyelinating disease appears to occur independently of $\mathrm{T}$ cells.

In diseases like MS, MHC II functions as an antigen presenting molecule to activate autoreactive $\mathrm{CD} 4^{+} \mathrm{T}$ cells. In fact, a link between MHC II and a propensity for diseases like MS has been established with a familial rate of occurrence approaching 20\% (Kalman and Lublin, 1999). Various MHC II molecules, such as DR15, DQ6, and Dw2, have been associated with either an increased or decreased propensity for MS in various populations (Kalman and Lublin, 1999). In the murine model for MS, EAE, susceptibility to disease is dependent on the MHC II haplotype, such as I- $\mathrm{A}^{\mathrm{u}}$ and I-A $\mathrm{A}^{\mathrm{s}}$, of a given animal (Fritz et al., 1985), and other studies using $T$ cell receptor transgenic mice and various encephalitogenic proteins have demonstrated a key role for antigen presentation in EAE (Wucherpfennig, 1994). The propensity for disease susceptibility in various haplotypes suggests a role for antigen presentation in MS and EAE.

A major function of microglia/macrophages in acute CNS inflammation is believed to be phagocytosis of myelin (Flaris et al., 1993; Nabavi et al., 1989; Perry, 1998; Perry and Gordon, 1988; Streit, 2002; Streit et al., 1988; Streit and Kreutzberg, 1988). Phagocytosis activates microglia/macrophages that results in the upregulation of various activation markers, such as MHC II, and secretion of proinflammatory cytokines (Gehrmann et al., 1995). It has been shown that phagocytised myelin peptides increase autoreactive $T$ cells (Zamvil et al., 1985; Zamvil and Steinman, 1990). However, microglia/macrophages expressing MHC II are also found in MS lesions where there are few T cells present ( $\mathrm{Li}$ et al., 1993; Raine, 1994). Additionally, a similar lack of T cells is found in neurological disorders such as Alzheimer's disease, Parkinson's disease, and Huntington's disease (Hickey et al., 1991; McGeer et al., 1989; McGeer et al., 1988a; McGeer et al., 1988b; McGeer et al., 1994). In such cases, the role of MHC II on microglia/macrophages is not clear.

The cuprizone-induced model for demyelination is ideal because the time course of cellular, biochemical, and morphological events is predictable and easily reproduced. In contrast to EAE, the lack of $T$ cell infiltrates in cuprizone-induced demyelination minimizes the possibility of the effect of antigen presentation on disease and eliminates confounding interpretation of results that might be attributed to T cells. In cuprizone-induced demyelination, MHC II is detected only on microglia/macrophages in vivo (Hiremath et al., 1998) (Arnett et al., 2003). Astrocytes can express MHC II in vitro, but these cells do not express MHC II in vivo during cuprizone intoxication (Arnett et al., 2003). We have shown in this study that $\mathrm{T}$ cells do not play a significant role in the disease process. Additionally, the C57BL/6 background $\left(\mathrm{H}-2^{\mathrm{b}}\right)$ of the mice treated with cuprizone (Hiremath et al., 1998) is ideal for determining a possible in vivo signaling function for MHC II because only the IA molecule is present. The I-E MHC II molecule is not expressed due to a mutation in the promoter of the $\alpha$ chain of the I-E molecule (Mathis et al., 1983). The $I-A_{\beta}$ cytoplasmic tail deletion mutation has previously been shown to eliminate a majority of the signal transduction function in vitro in B cell lines (Harton and Bishop, 1993), although in vitro evidence suggests that antigen-presenting cells function remains intact in $I-A_{\beta}{ }^{t r}$ mice (Smiley et al., 1995).

We speculate that MHC II may serve in signal transduction that activates microglia/ macrophages. Recently, several in vitro analyses have demonstrated that $\mathrm{T}$ cell-independent activation of MHC II on human monocytes and macrophages results in the secretion of various proinflammatory cytokines such as TNF- $\alpha$ and IL-1 $\beta$ (Espel et al., 1996; Fast et al., 1989; Matsuyama et al., 1993; Palkama and Hurme, 1993; Trede et al., 1991; Zembala et al., 1994). Furthermore, ample evidence from in vitro analyses suggest MHC II can signal to 
activate $\mathrm{B}$ cells or $\mathrm{T}$ cells and cause either differentiation, proliferation, or secretion of cytokines (Ahsmann et al., 1997; Baluyut et al., 1993; Bishop, 1992; Bishop and Frelinger, 1989; Bishop and Haughton, 1986; Cambier and Lehmann, 1989; Cambier et al., 1987; Chia et al., 1994; Damle et al., 1993; Harton and Bishop, 1993; Kanner et al., 1995; Lane et al., 1990; Mollick et al., 1991; Mooney et al., 1990; Naitoh et al., 1994; Newell et al., 1993; Spertini et al., 1992; Spertini et al., 1991; Wade et al., 1995). Thus, it is plausible that MHC II expressed on microglia/macrophages may signal similar activation with consequences that exacerbates disease. Our data showing reduced numbers of proliferating microglia/ macrophages and lower NO, TNF- $\alpha$, and IL- $1 \beta$ in the absence of the cytoplasmic tail in the $I-A_{\beta}{ }^{t r}$ mice supports this hypothesis and suggest this may be a novel mechanism by which microglia/macrophages become activated and exacerbate CNS pathology.

The results presented in this report demonstrate for the first time that the cytoplasmic domain of MHC II has a crucial role in vivo, and in our particular assays, it exacerbates CNS demyelination. Specifically, the cytoplasmic domain of MHC II appears to be important in activation of microglia/macrophages. These results are consistent with our previous findings in the murine model of Krabbe's disease, the twitcher mouse. By crossing the $I-A_{\beta}{ }^{t r}$ transgenic mice to twitcher to obtain $I-A_{\beta}{ }^{t r}$ twitcher mice, we found a similar reduction in the severity of demyelination compared to $I-A_{\beta}{ }^{+/+}$twitcher mice (data not shown). Both cuprizone-induced and twitcher models for demyelination corroborate the importance of the MHC II cytoplasmic tail in demyelinating disease.

These results are consistent with our hypothesis that during demyelination, MHC II molecules expressed on microglia/macrophages may serve as signaling molecules that lead to the activation and proliferation of microglia/macrophages accompanied by synthesis of cytokines associated with inflammation. The production of detrimental proinflammatory cytokines, such as TNF- $\alpha$ or IL-1 $\beta$, and substances such as nitric oxide may lead to oligodendrocyte perturbations that further exacerbate pathogenesis. These substances have repeatedly been shown to be produced by activated microglia/macrophages and to cause oligodendrocyte death in vitro (Merrill, 1991; Merrill et al., 1993; Selmaj and Raine, 1988). Our results in Figures 5 and 6 suggest that the increased presence of proinflammatory products in the cuprizone-treated $I-A_{\beta}{ }^{+/+}$mice compared to $I-A_{\beta}{ }^{-/-}$and $I-A_{\beta}{ }^{t r}$ mice might be contributing to the concomitant increased depletion of mature oligodendrocytes in the cuprizone-treated $I-A_{\beta}{ }^{+/+}$mice. This depletion of mature oligodendrocyte numbers is attributed to perturbed cells that show severe inhibition of MBP and MAG transcription (Morell et al., 1998), and subsequently undergo apoptosis (Mason et al., 2000). Our findings are in support of other investigators that have also postulated that microglia/macrophages may be detrimental to demyelinating disease (Stoll and Jander, 1999) (Gonzalez-Scarano and Baltuch, 1999).

We additionally demonstrate that $\mathrm{T}$ cells likely do not participate in cuprizone-induced demyelinating disease; hence the conventional role of MHC II as a ligand for T cells may not be occurring in this model. In this model, there are very few $\mathrm{T}$ cells as mentioned above in Results (McMahon et al., 2002) and negligible amounts of T cell-associated cytokines (IFN- $\gamma$ ) are present in the brain (unpublished results). Furthermore, we do not observe perivascular cuffing associated with conventional $\mathrm{T}$ cell-mediated demyelination in EAE or viral models and the blood-brain barrier remains intact in C57BL/6 mice during cuprizone exposure (McMahon et al., 2002). Finally, we do not observe CD4 expression at any time point during cuprizone-induced demyelination or remyelination in our microarray analyses (data not shown). These findings suggest $\mathrm{T}$ cells are not likely contributing to this disease process. To definitively determine whether $\mathrm{T}$ cells have a role in this disease, we have treated $R A G-1^{-1-}$ mice with cuprizone and found no differences in demyelination, in cellularity, or in the number of RCA- $1^{+}$microglia/macrophages (Figure 7B and data not 
shown). This demonstrates that microglia/macrophages per se in the absence of $\mathrm{T}$ lymphocytes may be equally prominent effector cells in exacerbating demyelinating disease. We have also demonstrated that MHC II is important for remyelination at week 7 and week 8; however, there, too, $\mathrm{T}$ cells do not play a role in remyelination (Arnett et al., 2001). Currently, it is not known how MHC II is being activated in our model in the absence of T cell function. However, we presume that activation through MHC II may cause the elevated release of proinflammatory substances that may be detrimental to mature oligodendrocytes during demyelination. Interestingly however, TNF- $\alpha$ appears to be detrimental to mature oligodendrocytes during demyelination, but essential for oligodendrocyte precursors during remyelination based on the respective cell type expression of TNFRI and TNFRII (Arnett et al., 2001). This depletion of mature oligodendrocytes is followed by an accumulation of $\mathrm{NG}^{+}$oligodendrocytes precursor cells (Mason et al., 2000); however, by week 5, the number of oligodendrocytes precursor cells in $I-A_{\beta}{ }^{-l-}$ mice was similar to $I-A_{\beta}{ }^{+/+}$mice (data not shown). It is plausible that the residual levels of TNF- $\alpha$ remaining in I-A mutant mice is sufficient to sustain oligodendrocytes precursor cells (Figure 5) or that factors other than TNF- $\alpha$ may be supporting oligodendrocytes precursor cell recruitment in $I-A_{\beta}{ }^{-1-}$ mice. Thus, we suggest that MHC II serves to activate microglia and secrete TNF- $\alpha$ and other factors, which at first may enhance demyelination but later contributes to facilitate remyelination. Further investigations may provide insights for the role of MHC II on microglia and potential oligodendrocyte interactions.

\section{Acknowledgments}

We acknowledge the generosity of Dr. L. Glimcher, Dr. M. Grusby, and Dr. S. Smiley for providing us with the $I$ $A \beta^{-l-}$ and $I-A \beta^{t r}$ mice. We further thank Dr. R. Bagnell for his help with microscopy, and Dr. C. Lawler for her help and expertise in statistical analysis. MMH was supported by the NIAID grant AI07273, the UNC Graduate Dissertation Completion Fellowship, and the UNC Medical Alumni Association Endowment Fund. VSC was supported by NIAID T32 AI07273. KS was supported by NINDS grants NS24453 and HD03110. JPYT was supported by NINDS grant NS35372 and NMSS grant RG7295. GKM was supported by NAID grant AI51770 and NMSS grant RG3898A.

\section{References}

Ahsmann EJ, Boom SE, Lokhorst HM, Rijksen G, Bloem AC. Anti-adhesive signals are mediated via major histocompatibility complex class II molecules in normal and neoplastic human B cells: correlation with B cell differentiation stage. Eur J Immunol 1997;27:2688-2695. [PubMed: 9368627]

Andre P, Cambier JC, Wade TK, Raetz T, Wade WF. Distinct structural compartmentalization of the signal transducing functions of major histocompatibility complex class II (Ia) molecules. J Exp Med 1994;179:763-768. [PubMed: 8294884]

Arnett HA, Mason J, Marino M, Suzuki K, Matsushima GK, Ting JP. TNF alpha promotes proliferation of oligodendrocyte progenitors and remyelination. Nat Neurosci 2001;4:1116-1122. [PubMed: 11600888]

Arnett HA, Wang Y, Matsushima GK, Suzuki K, Ting JP. Functional genomic analysis of remyelination reveals importance of inflammation in oligodendrocyte regeneration. J Neurosci 2003;23:9824-9832. [PubMed: 14586011]

Bakker DA, Ludwin SK. Blood-brain barrier permeability during Cuprizone-induced demyelination. Implications for the pathogenesis of immune-mediated demyelinating diseases. J Neurol Sci 1987;78:125-137. [PubMed: 3553434]

Baluyut AR, Pollok KE, Bondada S. Molecular events in B lymphocyte activation: consequences of signals transduced through MHC class II molecules. Cell Immunol 1993;147:353-366. [PubMed: 8453677]

Barnett MH, Henderson AP, Prineas JW. The macrophage in MS: just a scavenger after all? Pathology and pathogenesis of the acute MS lesion. Mult Scler 2006;12:121-132. [PubMed: 16629415] 
Beckman JS, Koppenol WH. Nitric oxide, superoxide, and peroxynitrite: the good, the bad, and ugly. Am J Physiol 1996;271:C1424-1437. [PubMed: 8944624]

Bishop GA. Signaling to a CD5+ B-cell clone through surface Ig and MHC class II molecules. Ann N Y Acad Sci 1992;651:228-240. [PubMed: 1376042]

Bishop GA, Frelinger JA. Haplotype-specific differences in signaling by transfected class II molecules to a Ly-1+ B-cell clone. Proc Natl Acad Sci U S A 1989;86:5933-5937. [PubMed: 2788281]

Bishop GA, Haughton G. Induced differentiation of a transformed clone of Ly-1+ B cells by clonal T cells and antigen. Proc Natl Acad Sci U S A 1986;83:7410-7414. [PubMed: 2945204]

Blakemore WF. Observations on oligodendrocyte degeneration, the resolution of status spongiosus and remyelination in cuprizone intoxication in mice. J Neurocytol 1972;1:413-426. [PubMed: 8530973]

Blakemore WF. Demyelination of the superior cerebellar peduncle in the mouse induced by cuprizone. J Neurol Sci 1973;20:63-72. [PubMed: 4744511]

Cambier JC, Lehmann KR. Ia-mediated signal transduction leads to proliferation of primed B lymphocytes. J Exp Med 1989;170:877-886. [PubMed: 2788709]

Cambier JC, Newell MK, Justement LB, McGuire JC, Leach KL, Chen ZZ. Ia binding ligands and cAMP stimulate nuclear translocation of PKC in B lymphocytes. Nature 1987;327:629-632. [PubMed: 3037375]

Cammer W, Zhang H. Atypical localization of the oligodendrocytic isoform (PI) of glutathione-Stransferase in astrocytes during cuprizone intoxication. J Neurosci Res 1993;36:183-190. [PubMed: 8263971]

Chia CP, Khrebtukova I, McCluskey J, Wade WF. MHC class II molecules that lack cytoplasmic domains are associated with the cytoskeleton. J Immunol 1994;153:3398-3407. [PubMed: 7930565]

Damle NK, Leytze G, Klussman K, Ledbetter JA. Activation with superantigens induces programmed death in antigen-primed CD4+ class II+ major histocompatibility complex T lymphocytes via a CD11a/CD18-dependent mechanism. Eur J Immunol 1993;23:1513-1522. [PubMed: 8100773]

Doyle C, Strominger JL. Interaction between CD4 and class II MHC molecules mediates cell adhesion. Nature 1987;330:256-259. [PubMed: 2823150]

Espel E, Garcia-Sanz JA, Aubert V, Menoud V, Sperisen P, Fernandez N, Spertini F. Transcriptional and translational control of TNF-alpha gene expression in human monocytes by major histocompatibility complex class II ligands. Eur J Immunol 1996;26:2417-2424. [PubMed: 8898955]

Fast DJ, Schlievert PM, Nelson RD. Toxic shock syndrome-associated staphylococcal and streptococcal pyrogenic toxins are potent inducers of tumor necrosis factor production. Infect Immun 1989;57:291-294. [PubMed: 2642470]

Flaris NA, Densmore TL, Molleston MC, Hickey WF. Characterization of microglia and macrophages in the central nervous system of rats: definition of the differential expression of molecules using standard and novel monoclonal antibodies in normal CNS and in four models of parenchymal reaction. Glia 1993;7:34-40. [PubMed: 8423060]

Fritz RB, McFarlin DE. Encephalitogenic epitopes of myelin basic protein. Chem Immunol 1989;46:101-125. [PubMed: 2482036]

Fritz RB, Skeen MJ, Chou CH, Garcia M, Egorov IK. Major histocompatibility complex-linked control of the murine immune response to myelin basic protein. J Immunol 1985;134:2328-2332. [PubMed: 2579140]

Gehrmann J, Matsumoto Y, Kreutzberg GW. Microglia: intrinsic immuneffector cell of the brain. Brain Res Brain Res Rev 1995;20:269-287. [PubMed: 7550361]

Germain RN. MHC-dependent antigen processing and peptide presentation: providing ligands for $\mathrm{T}$ lymphocyte activation. Cell 1994;76:287-299. [PubMed: 8293464]

Gonzalez-Scarano F, Baltuch G. Microglia as mediators of inflammatory and degenerative diseases. Annu Rev Neurosci 1999;22:219-240. [PubMed: 10202538]

Grusby MJ, Glimcher LH. Immune responses in MHC class II-deficient mice. Annu Rev Immunol 1995;13:417-435. [PubMed: 7612230] 
Grusby MJ, Johnson RS, Papaioannou VE, Glimcher LH. Depletion of CD4+ T cells in major histocompatibility complex class II-deficient mice. Science 1991;253:1417-1420. [PubMed: 1910207]

Harton JA, Bishop GA. Length and sequence requirements of the cytoplasmic domain of the A beta molecule for class II-mediated B cell signaling. J Immunol 1993;151:5282-5289. [PubMed: 8228224]

Hauschildt S, Bessler WG, Scheipers P. Engagement of major histocompatibility complex class II molecules leads to nitrite production in bone marrow-derived macrophages. Eur J Immunol 1993;23:2988-2992. [PubMed: 7693484]

Hauser SL, Bhan AK, Gilles FH, Hoban CJ, Reinherz EL, Schlossman SF, Weiner HL. Immunohistochemical staining of human brain with monoclonal antibodies that identify lymphocytes, monocytes, and the Ia antigen. J Neuroimmunol 1983;5:197-205. [PubMed: 6413533]

Hickey, WF. Psychoneuro-immunology. Ader, RC., editor. Academic Press; New York, NY: 1991. p. 149-175.

Hickey WF, Hsu BL, Kimura H. T-lymphocyte entry into the central nervous system. J Neurosci Res 1991;28:254-260. [PubMed: 2033653]

Hickey WF, Kimura H. Perivascular microglial cells of the CNS are bone marrow-derived and present antigen in vivo. Science 1988;239:290-292. [PubMed: 3276004]

Hiremath MM, Saito Y, Knapp GW, Ting JP, Suzuki K, Matsushima GK. Microglial/macrophage accumulation during cuprizone-induced demyelination in C57BL/6 mice. J Neuroimmunol 1998;92:38-49. [PubMed: 9916878]

Jones EY, Fugger L, Strominger JL, Siebold C. MHC class II proteins and disease: a structural perspective. Nat Rev Immunol 2006;6:271-282. [PubMed: 16557259]

Kalman B, Lublin FD. The genetics of multiple sclerosis. A review. Biomed Pharmacother 1999;53:358-370. [PubMed: 10554670]

Kanner SB, Grosmaire LS, Blake J, Schieven GL, Masewicz S, Odum N, Ledbetter JA. ZAP-70 and p72syk are signaling response elements through MHC class II molecules. Tissue Antigens 1995;46:145-154. [PubMed: 8525473]

Kondo A, Nakano T, Suzuki K. Blood-brain barrier permeability to horseradish peroxidase in twitcher and cuprizone-intoxicated mice. Brain Res 1987;425:186-190. [PubMed: 3427420]

Konig R, Huang LY, Germain RN. MHC class II interaction with CD4 mediated by a region analogous to the MHC class I binding site for CD8. Nature 1992;356:796-798. [PubMed: 1574118]

Konig R, Shen X, Germain RN. Involvement of both major histocompatibility complex class II alpha and beta chains in CD4 function indicates a role for ordered oligomerization in T cell activation. $\mathrm{J}$ Exp Med 1995;182:779-787. [PubMed: 7650484]

Kreutzberg GW. Microglia: a sensor for pathological events in the CNS. Trends Neurosci 1996;19:312-318. [PubMed: 8843599]

Lane PJ, McConnell FM, Schieven GL, Clark EA, Ledbetter JA. The role of class II molecules in human B cell activation. Association with phosphatidyl inositol turnover, protein tyrosine phosphorylation, and proliferation. J Immunol 1990;144:3684-3692. [PubMed: 1692059]

Li H, Newcombe J, Groome NP, Cuzner ML. Characterization and distribution of phagocytic macrophages in multiple sclerosis plaques. Neuropathol Appl Neurobiol 1993;19:214-223. [PubMed: 7689189]

Loughlin AJ, Honegger P, Woodroofe MN, Comte V, Matthieu JM, Cuzner ML. Myelin basic protein content of aggregating rat brain cell cultures treated with cytokines and/or demyelinating antibody: effects of macrophage enrichment. J Neurosci Res 1994;37:647-653. [PubMed: 7518010]

Ludwin SK. Central nervous system demyelination and remyelination in the mouse: an ultrastructural study of cuprizone toxicity. Lab Invest 1978;39:597-612. [PubMed: 739762]

Mason JL, Jones JJ, Taniike M, Morell P, Suzuki K, Matsushima GK. Mature oligodendrocyte apoptosis precedes IGF-1 production and oligodendrocyte progenitor accumulation and differentiation during demyelination/remyelination. J Neurosci Res 2000;61:251-262. [PubMed: 10900072] 
Mathis DJ, Benoist C, Williams VE 2nd, Kanter M, McDevitt HO. Several mechanisms can account for defective E alpha gene expression in different mouse haplotypes. Proc Natl Acad Sci U S A 1983;80:273-277. [PubMed: 6296871]

Matsushima GK, Taniike M, Glimcher LH, Grusby MJ, Frelinger JA, Suzuki K, Ting JP. Absence of MHC class II molecules reduces CNS demyelination, microglial/macrophage infiltration, and twitching in murine globoid cell leukodystrophy. Cell 1994;78:645-656. [PubMed: 8069913]

Matsuyama S, Koide Y, Yoshida TO. HLA class II molecule-mediated signal transduction mechanism responsible for the expression of interleukin-1 beta and tumor necrosis factor-alpha genes induced by a staphylococcal superantigen. Eur J Immunol 1993;23:3194-3202. [PubMed: 8258334]

Mattiace LA, Davies P, Dickson DW. Detection of HLA-DR on microglia in the human brain is a function of both clinical and technical factors. Am J Pathol 1990;136:1101-1114. [PubMed: 1693471]

McGeer PL, Akiyama H, Itagaki S, McGeer EG. Immune system response in Alzheimer's disease. Can J Neurol Sci 1989;16:516-527. [PubMed: 2804814]

McGeer PL, Itagaki S, Boyes BE, McGeer EG. Reactive microglia are positive for HLA-DR in the substantia nigra of Parkinson's and Alzheimer's disease brains. Neurology 1988a;38:1285-1291. [PubMed: 3399080]

McGeer PL, Itagaki S, McGeer EG. Expression of the histocompatibility glycoprotein HLA-DR in neurological disease. Acta Neuropathol (Berl) 1988b;76:550-557. [PubMed: 2974227]

McGeer PL, Rogers J, McGeer EG. Neuroimmune mechanisms in Alzheimer disease pathogenesis. Alzheimer Dis Assoc Disord 1994;8:149-158. [PubMed: 7986484]

McMahon EJ, Suzuki K, Matsushima GK. Peripheral macrophage recruitment in cuprizone-induced CNS demyelination despite an intact blood-brain barrier. J Neuroimmunol 2002;130:32-45. [PubMed: 12225886]

Mehindate K, al-Daccak R, Damdoumi F, Mourad W. Synergistic effect between CD40 and class II signals overcome the requirement for class II dimerization in superantigen-induced cytokine gene expression. Eur J Immunol 1996;26:2075-2080. [PubMed: 8814249]

Merrill JE. Effects of interleukin-1 and tumor necrosis factor-alpha on astrocytes, microglia, oligodendrocytes, and glial precursors in vitro. Dev Neurosci 1991;13:130-137. [PubMed: 1752215]

Merrill JE, Ignarro LJ, Sherman MP, Melinek J, Lane TE. Microglial cell cytotoxicity of oligodendrocytes is mediated through nitric oxide. J Immunol 1993;151:2132-2141. [PubMed: 8102159]

Mollick JA, Chintagumpala M, Cook RG, Rich RR. Staphylococcal exotoxin activation of T cells. Role of exotoxin-MHC class II binding affinity and class II isotype. J Immunol 1991;146:463468. [PubMed: 1987273]

Mooney NA, Grillot-Courvalin C, Hivroz C, Ju LY, Charron D. Early biochemical events after MHC class II-mediated signaling on human B lymphocytes. J Immunol 1990;145:2070-2076. [PubMed: 2398273]

Morell P, Barrett CV, Mason JL, Toews AD, Hostettler JD, Knapp GW, Matsushima GK. Gene expression in brain during cuprizone-induced demyelination and remyelination. Mol Cell Neurosci 1998;12:220-227. [PubMed: 9828087]

Nabavi N, Freeman GJ, Gault A, Godfrey D, Nadler LM, Glimcher LH. Signalling through the MHC class II cytoplasmic domain is required for antigen presentation and induces B7 expression. Nature 1992;360:266-268. [PubMed: 1279442]

Nabavi N, Ghogawala Z, Myer A, Griffith IJ, Wade WF, Chen ZZ, McKean DJ, Glimcher LH. Antigen presentation abrogated in cells expressing truncated Ia molecules. J Immunol 1989;142:1444-1447. [PubMed: 2918224]

Naitoh K, Ichigi Y, Miyake K, Muraguchi A, Kimoto M. Signal transmission through MHC class II molecules in a human B lymphoid progenitor cell line: different signaling pathways depending on the maturational stages of B cells. Microbiol Immunol 1994;38:967-976. [PubMed: 7723690]

Newell MK, VanderWall J, Beard KS, Freed JH. Ligation of major histocompatibility complex class II molecules mediates apoptotic cell death in resting B lymphocytes. Proc Natl Acad Sci U S A 1993;90:10459-10463. [PubMed: 8248132] 
Odum N, Martin PJ, Schieven GL, Hansen JA, Ledbetter JA. Signal transduction by HLA class II antigens expressed on activated T cells. Eur J Immunol 1991;21:123-129. [PubMed: 1703961]

Palkama T, Hurme M. Signal transduction mechanisms of HLA-DR-mediated interleukin-1 beta production in human monocytes. Role of protein kinase $\mathrm{C}$ and tyrosine kinase activation. Hum Immunol 1993;36:259-267. [PubMed: 8340234]

Perry VH. A revised view of the central nervous system microenvironment and major histocompatibility complex class II antigen presentation. J Neuroimmunol 1998;90:113-121. [PubMed: 9817438]

Perry VH, Gordon S. Macrophages and microglia in the nervous system. Trends Neurosci 1988;11:273-277. [PubMed: 2465626]

Prineas, JWM.; J.I.; Franklin, RJM. Demyelinating Diseases. In: Graham, DIL.; P.L., editors. Greenfield's Neuropathology. Arnold; 2002. p. 471-550.

Raine CS. Multiple sclerosis: immune system molecule expression in the central nervous system. J Neuropathol Exp Neurol 1994;53:328-337. [PubMed: 8021705]

Scholl PR, Trede N, Chatila TA, Geha RS. Role of protein tyrosine phosphorylation in monokine induction by the staphylococcal superantigen toxic shock syndrome toxin-1. J Immunol 1992;148:2237-2241. [PubMed: 1545128]

Selmaj KW, Raine CS. Tumor necrosis factor mediates myelin and oligodendrocyte damage in vitro. Ann Neurol 1988;23:339-346. [PubMed: 3132891]

Sidman, RL.; Abervine, JB.; Pierce, ET. Commonwealth Fund Book. Harvard University Press; Cambridge, MA: 1971. Atlas of the mouse brain and spinal cord.

Smiley ST, Laufer TM, Lo D, Glimcher LH, Grusby MJ. Transgenic mice expressing MHC class II molecules with truncated A beta cytoplasmic domains reveal signaling-independent defects in antigen presentation. Int Immunol 1995;7:665-677. [PubMed: 7547694]

Smiley ST, Rudensky AY, Glimcher LH, Grusby MJ. Truncation of the class II beta-chain cytoplasmic domain influences the level of class II/invariant chain-derived peptide complexes. Proc Natl Acad Sci U S A 1996;93:241-244. [PubMed: 8552613]

Spertini F, Chatila T, Geha RS. Signals delivered via MHC class II molecules synergize with signals delivered via TCR/CD3 to cause proliferation and cytokine gene expression in T cells. J Immunol 1992;149:65-70. [PubMed: 1376752]

Spertini F, Spits H, Geha RS. Staphylococcal exotoxins deliver activation signals to human T-cell clones via major histocompatibility complex class II molecules. Proc Natl Acad Sci U S A 1991;88:7533-7537. [PubMed: 1881894]

Stoll G, Jander S. The role of microglia and macrophages in the pathophysiology of the CNS. Prog Neurobiol 1999;58:233-247. [PubMed: 10341362]

Streit WJ. Microglia as neuroprotective, immunocompetent cells of the CNS. Glia 2002;40:133-139. [PubMed: 12379901]

Streit WJ, Graeber MB, Kreutzberg GW. Functional plasticity of microglia: a review. Glia 1988;1:301-307. [PubMed: 2976393]

Streit WJ, Kreutzberg GW. Response of endogenous glial cells to motor neuron degeneration induced by toxic ricin. J Comp Neurol 1988;268:248-263. [PubMed: 3360987]

Suzuki K, Kikkawa Y. Status spongiosus of CNS and hepatic changes induced by cuprizone (biscyclohexanone oxalyldihydrazone). Am J Pathol 1969;54:307-325. [PubMed: 5765567]

Taniike M, Suzuki K. Proliferative capacity of oligodendrocytes in the demyelinating twitcher spinal cord. J Neurosci Res 1995;40:325-332. [PubMed: 7745626]

Thomson G. HLA disease associations: models for the study of complex human genetic disorders. Crit Rev Clin Lab Sci 1995;32:183-219. [PubMed: 7598790]

Ting JP, Shigekawa BL, Linthicum DS, Weiner LP, Frelinger JA. Expression and synthesis of murine immune response-associated (Ia) antigens by brain cells. Proc Natl Acad Sci U S A 1981;78:31703174. [PubMed: 6166944]

Trede NS, Geha RS, Chatila T. Transcriptional activation of IL-1 beta and tumor necrosis factor-alpha genes by MHC class II ligands. J Immunol 1991;146:2310-2315. [PubMed: 2005400] 
Wade WF, Chen ZZ, Maki R, McKercher S, Palmer E, Cambier JC, Freed JH. Altered I-A proteinmediated transmembrane signaling in B cells that express truncated I-Ak protein. Proc Natl Acad Sci U S A 1989;86:6297-6301. [PubMed: 2503831]

Wade WF, Dickman DK, Peterson D, McCluskey J, Khrebtukova I. Class II cytoplasmic and transmembrane domains are not required for class II-mediated B cell spreading. Immunol Lett 1995;44:67-74. [PubMed: 7721346]

Wong GH, Bartlett PF, Clark-Lewis I, Battye F, Schrader JW. Inducible expression of H-2 and Ia antigens on brain cells. Nature 1984;310:688-691. [PubMed: 6433204]

Wucherpfennig KW. Autoimmunity in the central nervous system: mechanisms of antigen presentation and recognition. Clin Immunol Immunopathol 1994;72:293-306. [PubMed: 8062444]

Yagi T, McMahon EJ, Takikita S, Mohri I, Matsushima GK, Suzuki K. Fate of donor hematopoietic cells in demyelinating mutant mouse, twitcher, following transplantation of GFP+ bone marrow cells. Neurobiol Dis 2004;16:98-109. [PubMed: 15207267]

Zamvil S, Nelson P, Trotter J, Mitchell D, Knobler R, Fritz R, Steinman L. T-cell clones specific for myelin basic protein induce chronic relapsing paralysis and demyelination. Nature 1985;317:355358. [PubMed: 2413363]

Zamvil SS, Steinman L. The T lymphocyte in experimental allergic encephalomyelitis. Annu Rev Immunol 1990;8:579-621. [PubMed: 2188675]

Zembala M, Siedlar M, Ruggiero I, Wieckiewicz J, Mytar B, Mattei M, Colizzi V. The MHC class-II and CD44 molecules are involved in the induction of tumour necrosis factor (TNF) gene expression by human monocytes stimulated with tumour cells. Int J Cancer 1994;56:269-274. [PubMed: 7508890]

Zembowicz A, Vane JR. Induction of nitric oxide synthase activity by toxic shock syndrome toxin 1 in a macrophage-monocyte cell line. Proc Natl Acad Sci U S A 1992;89:2051-2055. [PubMed: 1372433] 


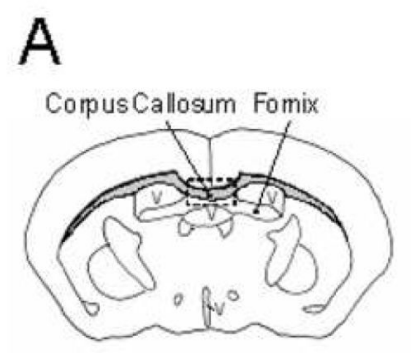

B

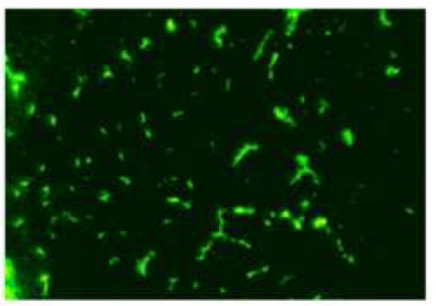

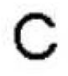

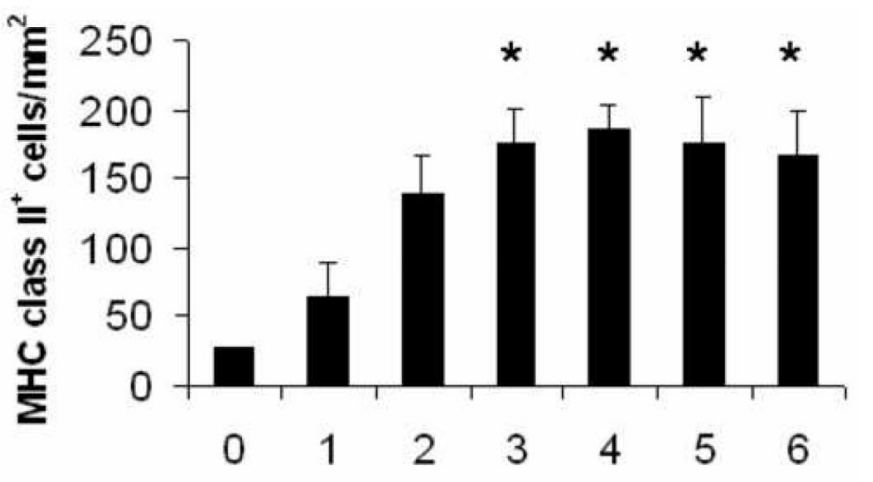

Weeks of $0.2 \%$ cuprizone treatment

Figure 1.

MHC class $\mathrm{II}^{+}$cells were detected in the corpus callosum of cuprizone-treated mice.

(A) Illustration of the corpus callosum from which all coronally-sectioned mouse brains were analyzed near midline within the rectangular box. $\mathrm{V}=$ ventricle

(B) Brain sections were stained with anti-I-A ${ }^{\mathrm{b}}$ antibody to identify $\mathrm{MHC}$ class $\mathrm{II}^{+}$cells in the demyelinated corpus callosum at week 3.0 (200X magnification).

(C) $\mathrm{MHC}$ class $\mathrm{II}^{+}$cells were quantified at weekly intervals during the 6 week exposure to cuprizone and were compared to untreated mouse brains (week 0 ). *Denotes $\mathrm{p}<0.05$ by oneway analysis of variance (ANOVA) test followed by Dunnett multiple comparisons test comparing all time points to 0 week timepoint; $n=3$ mice each week 

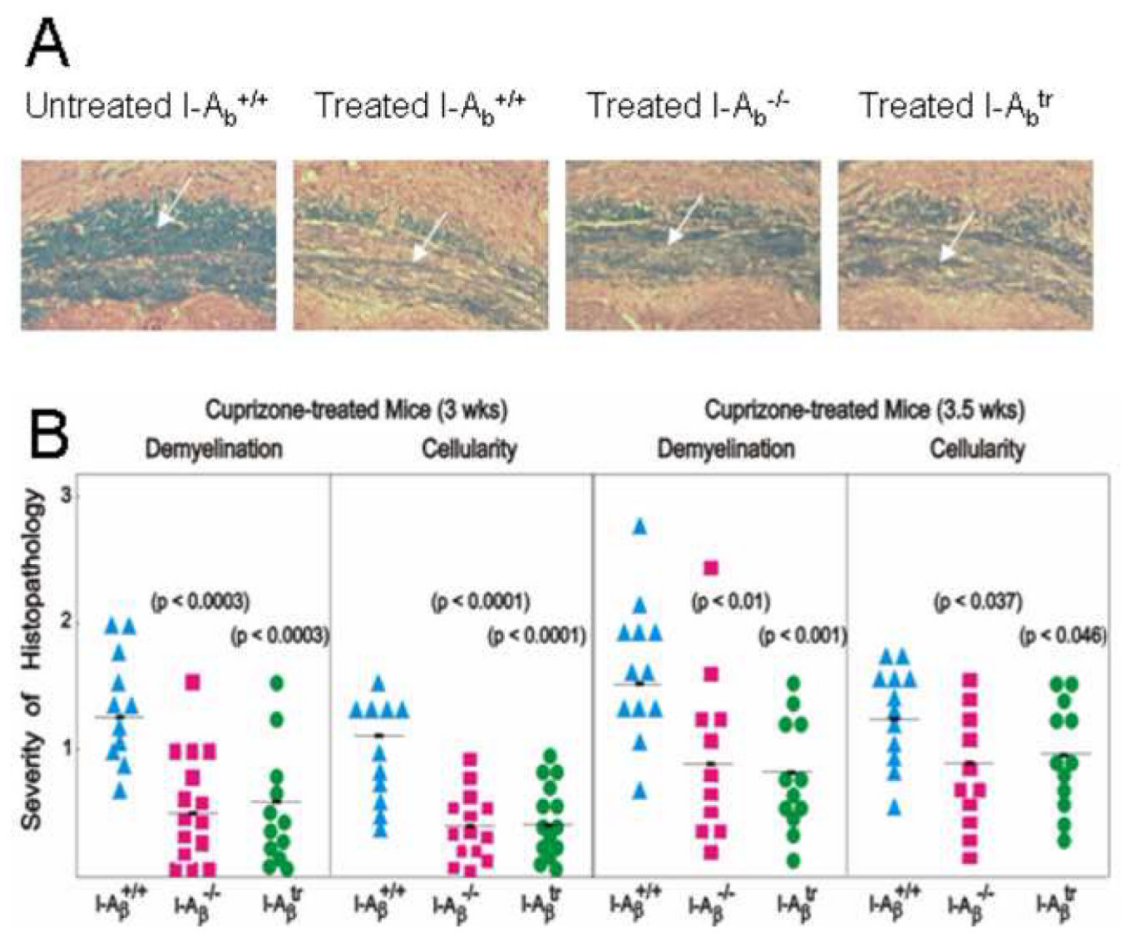

Figure 2.

Mice exhibited reduced demyelination in the corpus callosum when MHC class II was absent or when the cytoplasmic tail was truncated.

(A) LFB-PAS-stained coronal brain sections exposing the corpus callosum (indicated by the arrow) showed blue-stained myelin in untreated $I-A_{\beta}{ }^{+/+}$mice. Treatment of wild type, $I-$ $A_{\beta}{ }^{-/-}$, and $I-A_{\beta}{ }^{t r}$ mice with cuprizone for three weeks induced demyelination that is indicated by the lack of blue and the presence of pink counterstained fibers. Wildtype mice had significantly greater demyelination (indicated by the decreased blue staining) compared to $I-A_{\beta}{ }^{-I-}$ and $I-A_{\beta}{ }^{t r}$ mice. All pictures are shown at $100 \mathrm{X}$ magnification.

(B) The histopathology of the corpus callosum in the $I-A_{\beta}{ }^{-/-}$and the $I-A_{\beta}{ }^{t r}$ mouse was significantly reduced when compared to the wild type mouse. Brain sections were scored by three independent readers in a double-blind manner for the severity of demyelination and cellularity on a scale of zero to three and averaged as previously described (Hiremath et al., 1998). A score of 3 indicated complete demyelination, and a score of 1.5 indicated demyelination of $50 \%$ of the fibers. A score of zero indicated the lack of demyelination. Similarly, peak cellularity indicated by numbers of nuclei at week 5 of cuprizone treatment was taken as a score of 3 while untreated control was given a score of zero. Statistical analyses were conducted by ANOVA followed by the Dunnett multiple comparisons test which compared the wild type to $I-A_{\beta}{ }^{-/-}$or $I-A_{\beta}{ }^{\text {tr }}$ mice. Results are from three independent experiments using 4 mice per group per time point. 
A
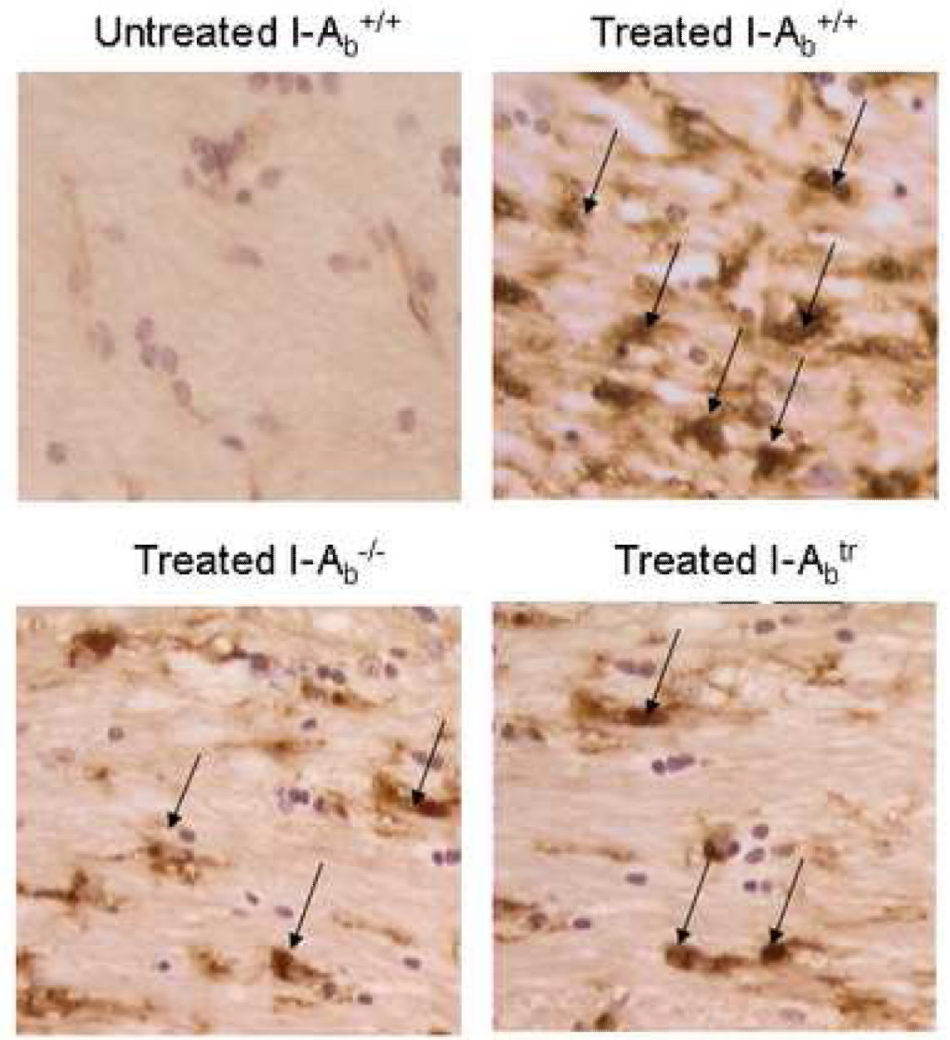

\section{B}

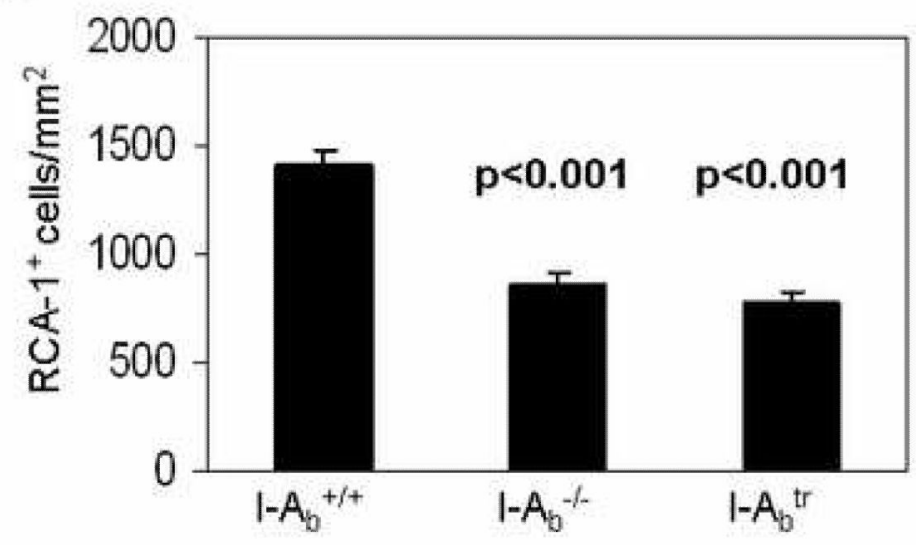

Figure 3.

The absence of MHC class II or the cytoplasmic tail of MHC class II showed a reduced microglia/macrophage accumulation in the corpus callosum.

(A) Representative RCA-1-stained microglia/macrophages (brown-stained cells with nuclei and indicated by arrows) in the corpus callosum of untreated controls wild type, $I-A_{\beta}{ }^{-/-}$, and $I-A_{\beta}{ }^{t r}$ mice treated for 3 weeks with $0.2 \%$ cuprizone at $400 \mathrm{X}$ magnification are shown.

(B) Morphometric quantitation of $\mathrm{RCA}-1^{+}$microglia/macrophages were facilitated by using the NIH Imaging software (Hiremath et al., 1998). The corpus callosum of wild type mice treated with cuprizone ( $n=12$ per genotype) for three weeks had greater numbers of 
microglia/macrophages than $I-A_{\beta}{ }^{-l-}$ or $I-A_{\beta}{ }^{t r}$ mice. Statistical analyses were conducted by ANOVA using the Dunnett multiple comparison test comparing to wild type mice. 


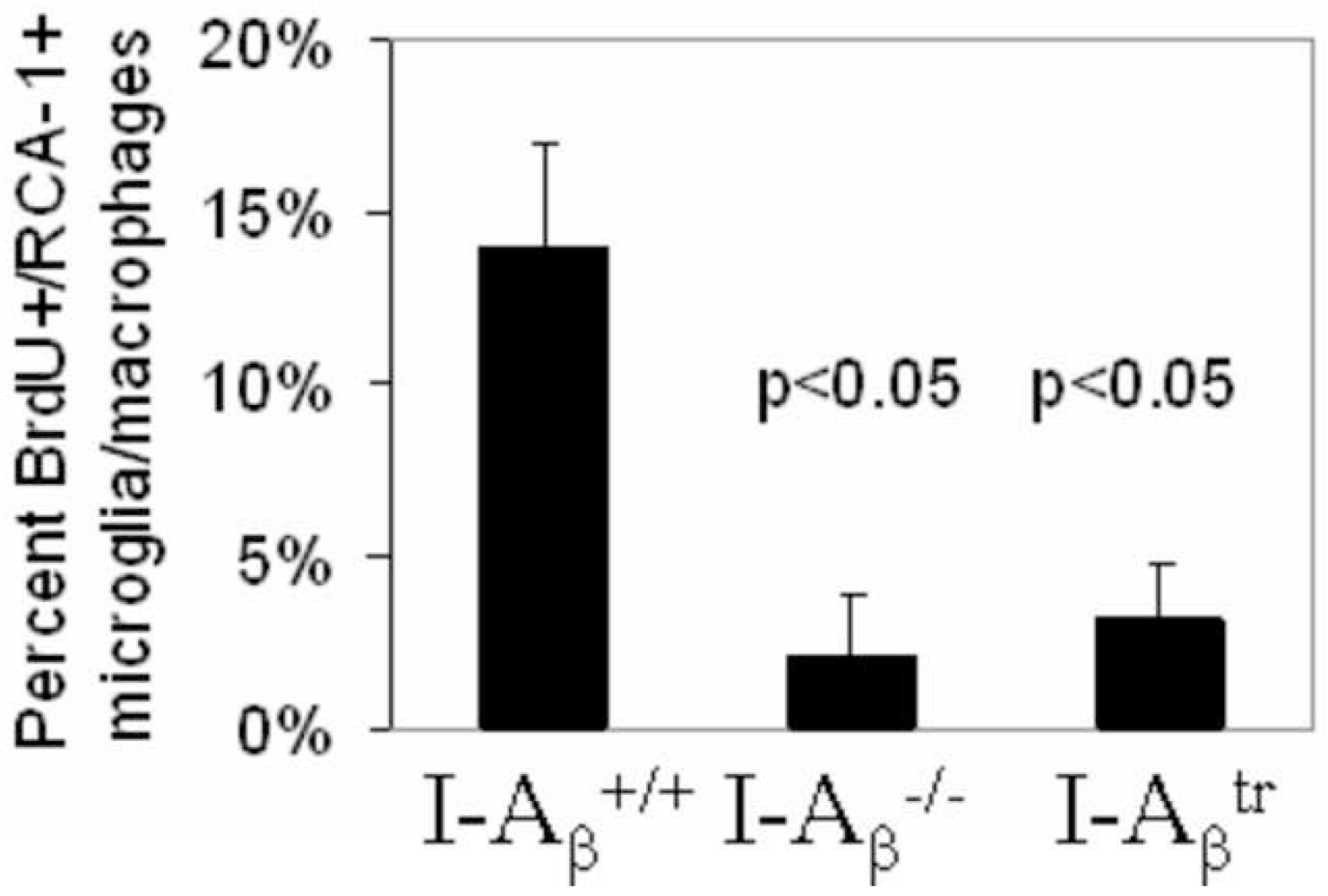

Figure 4.

BrdU incorporation is increased in wild type microglia/macrophages following cuprizone treatment.

The percent of RCA- $1^{+}$microglia/macrophages which incorporated BrdU at the 3 week treatment point ( $\mathrm{n}=4$ per genotype) was greater in wild type mice than in $I-A_{\beta}{ }^{-/-}$or $I-A_{\beta}{ }^{t r}$ mice. Statistical analysis was conducted using the Kruskal-Wallis nonparametric ANOVA test because the values did not fall within a normal U-shaped distribution. 


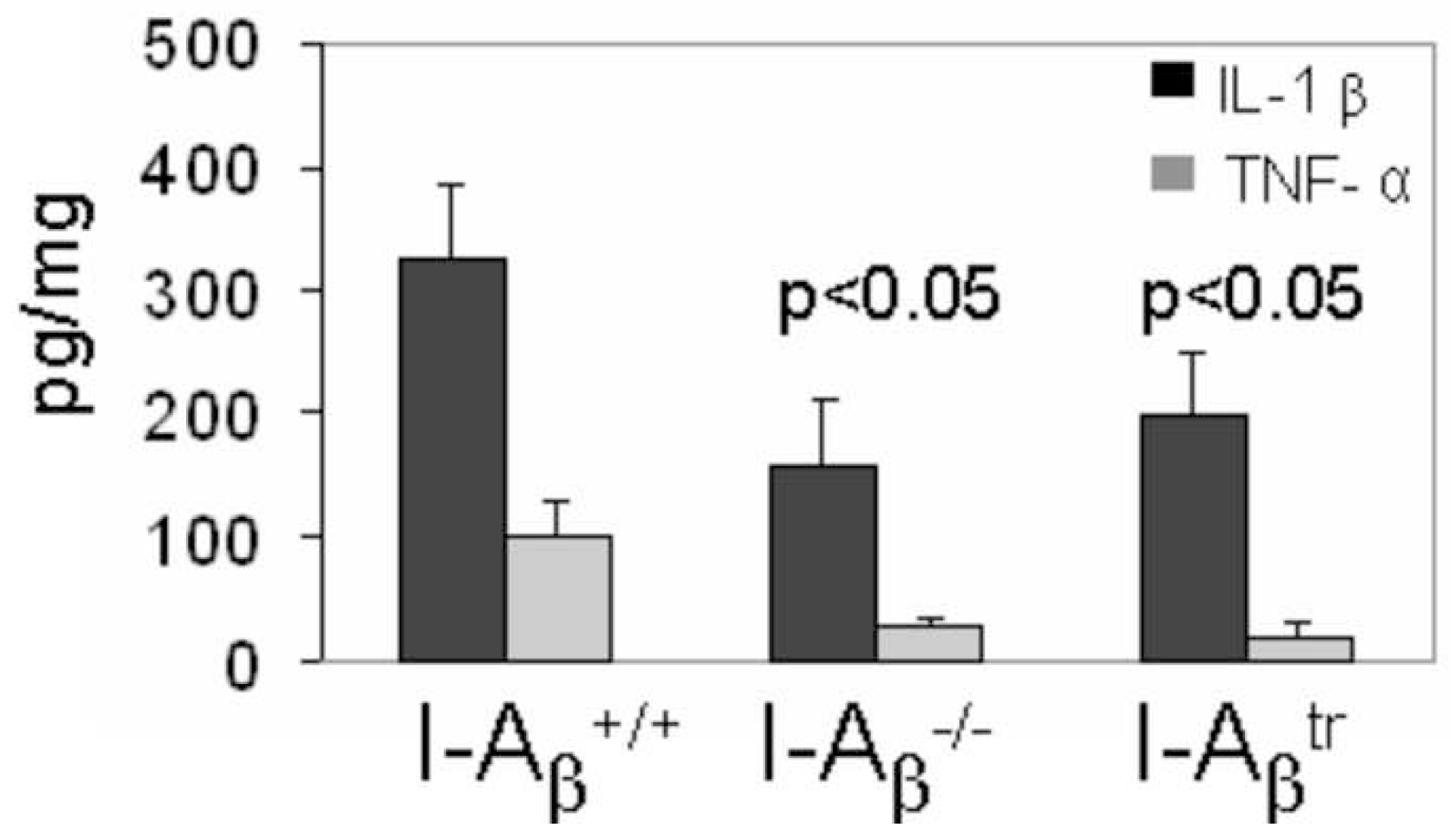

Figure 5.

TNF- $\alpha$ and IL-1 $\beta$ production in the brains of wild type mice was greater than $I-A_{\beta}{ }^{-/-}$and $I$ $A_{\beta}{ }^{t r}$ mice ( $\mathrm{n}=9-12$ mice per genotype).

Brains of cuprizone-treated mice were homogenized in the presence of protease inhibitors and extracts were assayed for TNF- $\alpha$ and IL- $1 \beta$ using EIA. Statistical analyses were conducted by ANOVA using the Dunnett multiple comparison test comparing to wild type mice. 


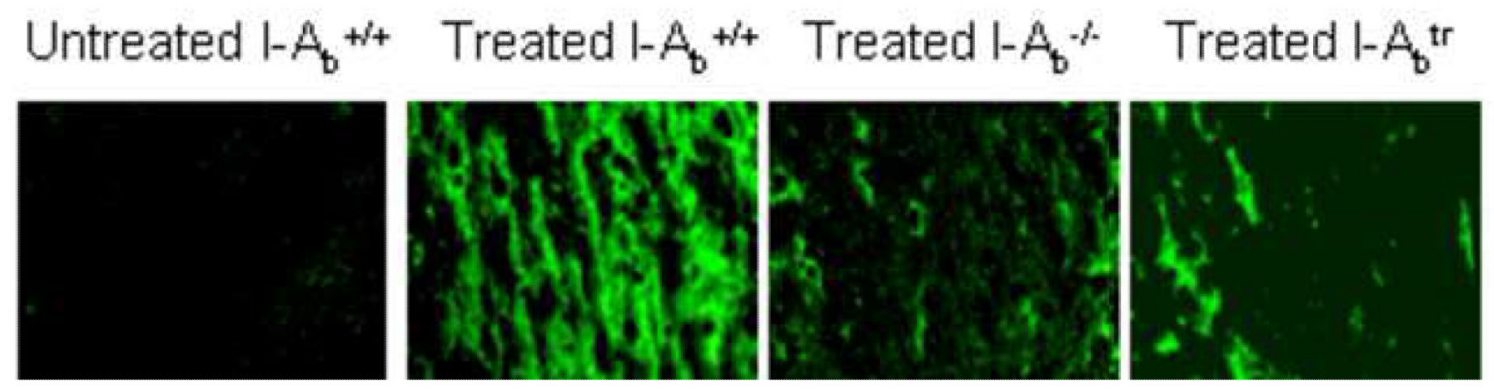

Figure 6.

Nitrotyrosine staining was increased in cuprizone-treated wild type mice. The lack of nitrotyrosine staining indicated the absence of nitric oxide in the corpus callosum of untreated control mice, but its presence in 3 week, cuprizone-treated wild type mice. The level of nitrotyrosine staining was reduced in cuprizone-treated $I-A_{\beta}{ }^{-I-}$ and $I-A_{\beta}{ }^{t r}$ mice $(\mathrm{n}=$ 4-5 mice per genotype). 
A

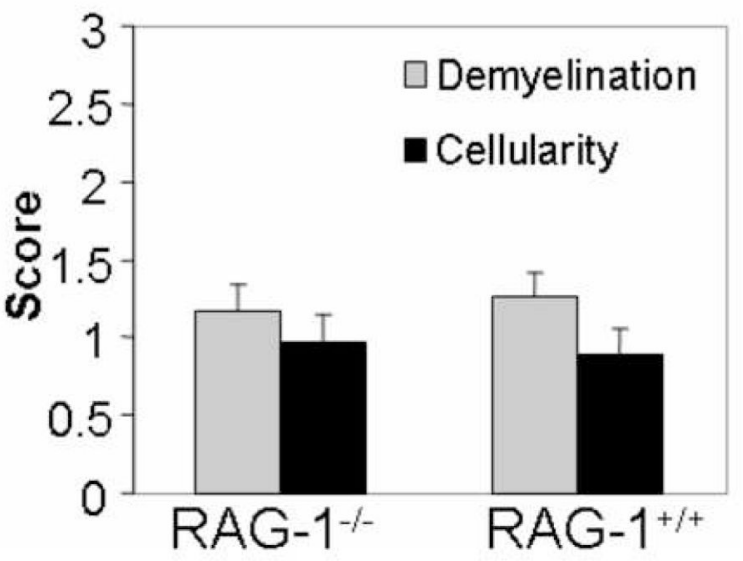

B

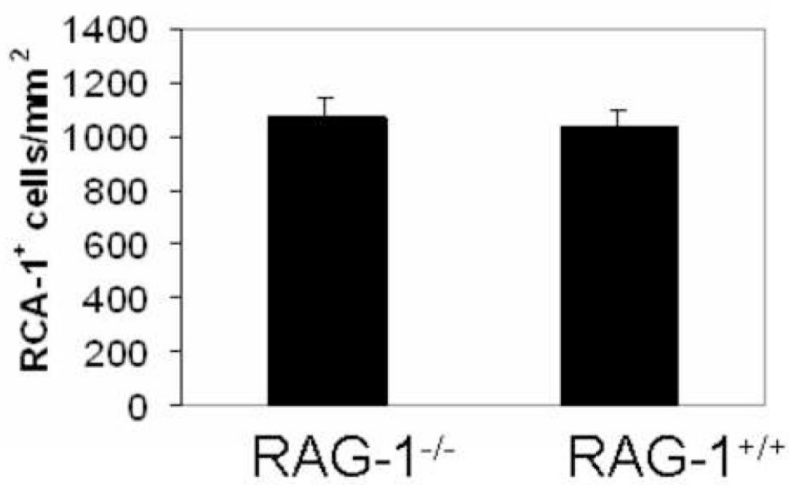

Figure 7.

Cuprizone-induced neuropathology and microglia/macrophage numbers were not affected by the $R A G-1^{-1-}$ mutation.

(A) $R A G-1^{-/-}$and $R A G-1^{+/+}$mice exhibit a similar degree of demyelination and cellularity at 3 weeks ( $\mathrm{n}=11-12$ per genotype). Three independent experiments were conducted using 3 or 4 mice per genotype. LFB-PAS- and RCA-1-stained coronal brain sections were scored as described in Figure 2 and Figure 3, respectively.

(B) Quantitation of the RCA- $1^{+}$microglia/macrophages revealed no statistical difference in the brains of $R A G-1^{-/-}$and $R A G-1^{+/+}$mice ( $\mathrm{n}=11-12$ per genotype) as described in Methods section. Statistical analysis was conducted using ANOVA comparing wild type to $R A G-1^{-/-}$mice. 